\title{
16. Kumo Koimbo: Accounts and Responses to Witchcraft in Gor, Simbu Province
}

\author{
Clara Bal
}

\section{Introduction}

United Nauro Gor is located in Kundiawa Gembogl District, Simbu Province, in the highlands of Papua New Guinea. The Gor Community Base Laws were enacted in 2006, along with establishment of a local police force to enforce the laws. The community made the laws because it faced many social problems. These included election-related tribal fights every five years, a high incidence of sorcery-related killings, and a general breakdown in law and order. The community, with the assistance of the then Catholic parish priest, Father Dr Jan Jaworski, village leaders and educated professionals, helped to draft the community laws. After the laws were implemented, young men and women from the community were recruited by the Royal Papua New Guinea Constabulary as auxillary police to enforce the laws within the community. The state supported these initiatives by training the local police and assigning a senior sergeant to help local police. The state also provided the Gor police with a car to carry out their tasks.

\section{Methodology}

I conducted a case study that began with researching reports and DVDs that were produced by the United Nauro Gor Association from its beginning until the present day. I held interviews with the former parish priest of Gor, Father Jaworski, whom the Gor community appointed as their village chief and also the person who helped the people to create the association.

The research involved quantitative and qualitative methods and observation.

One-on-one interviews were conducted with key individuals of Gor and also with individuals who had been directly associated with community projects. 
Interviews were carried out in different locations and people of both sexes and all ages were interviewed. Group interviews were carried out with local police officers including the senior sergeant.

Questionnaires were given out to get the views of the people living in the neighbouring communities of Gor. Questionnaires were also given out to the officers in charge of community policing in Simbu Province.

There were some limitations to the data collection. Some questionnaires were not returned and the geographical location of some villages made it impossible to reach them.

\section{Description of kumo}

Witchcraft is called kumo in the Kuman language of the Nauro people. Kumo koimbo is a term in the Kuman language that refers to a person who has kumo and practises it. People in the Nauro community believe that kumo koimbo has existed since the days of our forefathers. During the days of our forefathers, the kumo koimbo did not practise kumo openly as is done today.

It is believed in my community that a kumo koimbo is a person possessed by an evil spirit which is the kumo. The kumo that lives inside the kumo koimbo compels and controls the kumo koimbo (demon-possessed person) to do things he would not otherwise do if he were not possessed; for example, causing death, eating human flesh and waste, or removing and eating pigs' hearts while the pig is alive. Kumo koimbo also destroy students' education by cursing them so that the student does not complete their studies.

Kumo manifests in different forms in the United Nauro Gor community, mostly in the form of animals such as flying foxes, rats, dogs, cats, goats, cows and snakes. It is believed that when a kumo leaves the kumo koimbo's body and travels out into the night to kill someone or look for its food (human waste, flesh, and pigs' hearts) the kumo koimbo will sleep like a dead person. People could do anything to try to wake them, but the kumo koimbo will not respond. They will wake up only when the kumo returns to them.

Ordinary people do not know how kumo is passed from one person to another. The kumo koimbos know how they pass kumo to another person but never tell ordinary people how they do it. The only time people know that someone has been given kumo is when someone is caught in the act of practising kumo. It often happens with little children.

Kumo koimbo kill people for the following reasons: 


\section{Money}

The people believe that kumo kill people because of money. If a person has a lot of money and shares it among his or her relatives in the village and forgets to give some money to a kumo koimbo in the village, the kumo koimbo becomes angry and kills the person. Sometimes if a kumo koimbo sees that a particular family has a lot of money, the kumo koimbo will kill a family member - most often the head of the family — so that the family will spend the money in a way that benefits the kumo koimbo. For example, the relatives of the deceased will spend their money in the haus krai. The belief of kumo in my village encourages people to share.

\section{Jealousy}

Kumo koimbo also kill people out of jealousy. This often happens to business people and educated people. Kumo koimbo kill these people because they are jealous of them and the benefits they bring to their immediate family.

\section{Food}

Kumo koimbo also kill people because of food. If a particular family eat food such as rice, or any kind of protein, especially pork, and if they do not share the food with their neighbour who is a kumo koimbo, then the kumo koimbo will kill a member of the family. Therefore the people in the village are always careful when they eat the kind of food that they know the kumo koimbo likes eating as well.

\section{Reasons why people kill kumo koimbos}

People in my community kill kumo koimbo for reasons of retribution. Firstly, whenever a young and highly educated man or woman in our community dies suddenly without any obvious cause, kumo is suspected.

When such young people die, it is a loss to the family, clan, tribe and community as a whole. In my community, our people take pride in their educated sons and daughters. That is because the entire family or clan normally contributes to paying for their sons' or daughters' education, especially when they are attending higher secondary school to college and university.

It takes years and money to educate a young man or woman. When such educated persons die because of a kumo koimbo, the pain and loss that the family and the clan feels is great because a highly educated person cannot be easily replaced. 
Secondly, when young children, young men and women, or mothers die without any obvious cause, such as sickness, kumo is suspected. Sudden deaths of small children or young men or women in the village frustrate the community. Thus the community reacts by accusing and killing a person who is a known kumo koimbo in the village.

When the community kills a kumo koimbo it is often done in public or in broad daylight so that the entire community can see it. That is done intentionally to deter other kumo koimbo from killing innocent people in the village for no good reason.

\section{Accusation}

There are three main ways the people use to identify a person who practises kumo. Firstly, there are customary rules that the community follows during the mourning period. These are: women and men are not allowed to do marketing or sell their garden products, the people are not allowed to wash until after the mourning period, no work is allowed such as gardening or building of houses, children are not allowed to play, and no one in the village is allowed to whistle or laugh. If any of the people break one of these rules then the community will accuse that person.

Secondly, if any of the deceased's relatives had an argument with the deceased (and said something like 'you will live longer on this earth and continue to argue with me'), or if they gave food to him or her, and the person fell sick and died, the other relatives will accuse that relative of killing that person.

Thirdly, there are some people in Gor as well as in other rural communities in Simbu Province called kumo doctors. Kumo doctors are people who have kumo but the difference is the kumo doctors do not kill people but they expose other kumo koimbo. Kumo doctors act as doctors and they cure people who have been attacked and injured by other kumo koimbo.

When someone dies in the village and it is suspected that he or she was killed by a kumo koimbo, the relatives of the diseased hire a kumo doctor to come and identify the kumo koimbo responsible for the death of that person. It is a paid job.

\section{Gor Community Base Laws}

Sorcery-related accusations and killings were one of the challenges faced by the people of United Nauro Gor. Before the implementation of the laws, in every death there was more than one person being killed. Innocent people were also 
accused of possessing kumo and were discriminated against within the village. The accused would sometimes migrate to other provinces in the country, in order to protect their identity as well as their children from the discrimination. The people became aware that this evil practice was destroying their communal life and wanted to put a stop to it but they don't have a well-organised community and no one was there to empower them to take any action.

In response to this situation Father Jan Jaworski, the then parish priest of Yombar Catholic Church in Gor, began to talk with the community leaders about ways to improve these circumstances. This resulted in the creation of the United Nauro Gor Association with elected directors and executive. The people even changed the name of the community from Nauro Gor to United Nauro Gor. This made the people feel that they actually belonged to a community. The people in the community supported this idea because they knew that sorcery-related accusations and killings were damaging communal life. At the grassroots level the community really wanted to end this practice of sorcery-related accusations and killings, and also rape cases. The people in the community supported Father Jaworski and their village leaders by writing their own laws. The laws were publicly discussed and debated in Gor and the entire community (including men, women and children) took part in discussions and setting the penalty for breaching the laws. The elected executives had a final meeting and came up with the amended laws. They received formal endorsement across the community and were launched on 29 December 2006. A memorandum of understanding between the Royal Papua New Guinea Constabulary and Simbu administration was signed. The laws were presented to the people by their village chief, Bruno. The people in the community agreed to follow the laws. At first nothing happened. However, after the implementation of the Gor police the executives had a meeting and Bruno told them that the community law was working.

The people in the community are aware and have agreed that accusing someone of practising sorcery and rape are criminal cases. They won't accept compensation (which is the traditional law), but will bring the culprit to justice.

An extract of the Gor Community Base Laws that addresses sorcery-related violence appears at the end of this chapter. Sanguma and kumo have the same meaning; however, sanguma is Tok Pisin and kumo is from the Kuman language. The laws use the Tok Pisin term sanguma.

\section{Gor police}

The Gor Community Base Laws did not work at first because security was needed to enforce them. Therefore the Gor Community Police was formed. The village leaders selected strong and brave warriors in the village and recruited them as 
the Gor police. They also selected 30 women in the community and recruited them as policewomen. This was to show and teach the local people about the practice of gender equality. Although the memorandum of understanding stated that Simbu Province would support their training, financial assistance was not given. Instead, the provincial government assigned a senior sergeant to be with the police and also train them. The Gor Community Police received financial support from Caritas Australia and Mathew Siune, a former politician, gave 3000 kina for their training. The Simbu provincial government bought the uniforms. On my last interview with the Gor police as well as with the people in the community I noted that the Gor Community Police were not in the community performing their duties. But they were always in town helping out the regular police perform their jobs. This is because they are not being given allowances; at least some kind of income. Therefore they are doing other work to get money.

\section{Recommendations}

Creation of the Gor Community Base Laws and their enforcement by the Gor Community Police has had a very positive impact in the community. All that is needed now is more awareness to be conducted in the community to point out the positive impact the laws have had and encourage the people to continue to uphold and obey the very laws that they have made themselves.

The Gor Community Police need government assistance in terms of funding to conduct more workshops to educate the local community policemen and policewomen about basic constitutional rights of the people while executing their duties in the community.

The Simbu Government also should give allowances or income to the police in order to keep them in the village and stop the provincial police commander hiring them or taking them out from the village to perform other jobs.

Because of the fact that everyone in the community is living under permanent fear on their own land I also recommend that if we really want to cease sorceryrelated killings and rape we should work in the community at a grassroots level. Community laws needs to be worked out and endorsed by the community itself.

Prior to introducing community laws the community must have an organised structure. Their leadership must be trusted and respected.

In order for policing to be effective it needs to be community based. But community-based laws and community policing will not work in a community that is not organised. 


\section{Conclusion}

The people from United Nauro Gor came up with their community-based laws after the community was organised and received the structure of an organised association. The creation of the United Nauro Gor Association brought recovery of leadership and trust back to the community. Important factors were:

- the community was organised

- structure and leadership was created: a chairman, executives, body of directors and eight committees. The committees have regular meetings and the directors meet four times a year

- trust - people who are responsible and willing to work for the community

- the Gor Community Base Laws were written

- law enforcement was supported by community policing.

Community-based law and policing work hand in hand. I say this because after the Community Base Laws were implemented the community agreed that they would follow their own laws by June. However, they did not follow their own laws. The Nauro Gor Association then came up with the creation of community policing. After community policing was implemented the community leader reported to the association that the community laws were working.

After studying the United Nauro Gor Community Policing and Law, the community itself can address the issues on kumo (sanguma) and rape. However, not all members of the community will address the issues of kumo and rape. In order to address these issues, the community should build a good structure of leadership and should work and respect their leaders. The community should come up with a constructive and workable community. The people in the community know that sorcery-related accusations are destroying community life but they are not empowered to do anything to stop people from accusing other people. Therefore, if we want to help address this issue we should go to the community and start working at a grassroots level and empower the people to come up with a more organised community structure. 


\section{Appendix: Extract from Gor Community Base Laws and Policeing}

\subsection{Sanguma na Poisen [Sanguma and poison]}

Mi Nauro i tok nogat tru long toktok belong sanguma na poison.

[As a person of the Nauro community I solemnly declare that I will never talk about witchcraft and poison.]

3:1 Makim man nating long saguma bai chargim em long baim K500.00 wantim threepela bikpela pik inap long kaikai igo long man em makim olsem sanguma. Bai kotim yu long Deformation of Character.

[3:1 If a person in the village accuses someone of sorcery, that person will give the accused K500.00 and three big pigs. Plus the accuser will be charged with defamation of character.]

\section{3:1:1 Court fine em K200.00.}

3:2 Patim man o assoultim bai go long bikpela kot na kot i mekim save long em

[3:2 If a person is accused of practising sorcery and is assaulted by other people in the community, these people will be taken to either the district or the national court.]

Mas referim i go long Police, em Police Case.

[This case must be referred to the police.]

3:2:1 Village kot bai appeal i go long higher kot wantaim bakrap report.

[3:2:1 If the village court is biased this case will be referred to the district court.]

3:3 Killim man indai mas go long bikpela kot na kot i mas kalabusim ol man i mekim indai narapela.

[3:3 If someone is found guilty of taking the life of an accused person, he should be sent to prison. The person should be taken to a district or the national court.] 
Mas referim i go long Police, em Police Case.

[This case must be referred to the police.]

3:3:1 Village court bai no nap long stretim, bai appeal i go long higher court long stretim.

[3:3:1 The village court will not handle this case. It must be resolved in a higher court.]

3:3:2 Sapos lain bilong man indai lakim compensiation bai baim yet behind long higher court decision.

[3:3:2 Compensation to the relatives of the accused may be given after the court decision is made. That is, only if the relatives of the deceased want compensation.]

3:3:3 Tambu tru long lain supportim long kilim man long sangum, sapos husait man i supportim man long kilim man bai kisim same charge olsem man kilim narapela indai.

[3.3.3 People are not allowed to take part in killing an accused person. If someone supports another person in killing an accused, he or she will also be charged with murder.]

Mas referim i go long Police, em Police Case.

[This case must be referred to the police.]

3:4 Man indai ausait na ino sawe as belong indai mas karim indai man o meri igo long haus sik bilong wokim postmortem na kisim medical repot.

[3:4 If a person dies in the village and if their relatives do not know the cause of death they must take the deceased to the hospital for a post-mortem. They should get a medical report.]

3:5 Man indai long haus sik mas kisim full medical report before kisim dead body ikam autsit long planim.

[3:5 If a person dies in hospital, their relatives must get the medical report before bringing the deceased home for burial.] 
This text is taken from Talking it Through: Responses to Sorcery and Witchcraft Beliefs and Practices in Melanesia, edited by Miranda Forsyth and Richard Eves, published 2015 by ANU Press, The Australian National University, Canberra, Australia. 